\title{
Slovanski antroponimi v toponimiji Tolminske
}

\author{
Silvo Torkar
}

V prispevku je obdelanih 17 zemljepisnih imen z ozemlja sedanje tolminske občine, ki jih je mogoče utemeljeno razložiti iz slovanskih osebnih imen. Nekatera od njih doslej še niso bila predmet znanstvene obravnave ali pa so bile nezadovoljivo predstavljene besedotvorne in glasoslovne značilnosti njihovega nastanka.

Ključne besede: slovenski jezik, zemljepisna imena, Tolminska, slovanski antroponimi

\section{Slavic anthroponyms in the toponymy of the Tolmin region}

This article examines seventeen geographical names in the Municipality of Tolmin that can be explained on good grounds based on Slavic personal names. Some of these have not yet been examined linguistically, or the explanations of their word-formational and phonological origins have been unsatisfactory.

Key words: Slovenian, geographical names, Tolmin area, Slavic anthroponyms

Predmet pričujočega prispevka so zemljepisna imena na ozemlju sedanje tolminske občine, ki jih je mogoče utemeljeno razložiti iz slovanskih osebnih imen. Nekatera od njih doslej še niso bila predmet znanstvene obravnave ali pa so bile nezadovoljivo predstavljene besedotvorne in glasoslovne značilnosti njihovega nastanka. Navedena kategorija zemljepisnih imen je zaradi velike časovne odmaknjenosti njihovega nastanka današnjemu človeku precej odtujena, zato marsikdaj tudi pri jezikovno izobraženih ljudeh ni ustrezno ozaveščena in poznana. Deloma so za to krivi tudi obstoječi učni programi slovenščine, ki imenoslovnim vprašanjem skorajda ne namenjajo pozornosti. Po drugi strani se danes v Sloveniji srečujemo z diletantskim iskanjem keltskih, venetskih in drugih substratnih elementov v slovenskih zemljepisnih imenih in ljudski kulturi. Za nekatere slovenske intelektualce je značilno nekakšno nelagodje ob misli na slovanske korenine slovenskega jezika in velike večine zemljepisnih imen na Slovenskem, zato bomo poskusom prevrednotenja slovenske jezikovne in kulturne dediščine v smeri »razslovanjenja« očitno še priča.

Najširše vzeto so krajevna in sploh zemljepisna imena nastala iz treh virov: (a) iz občnih imen (apelativov), (b) iz osebnih imen (antroponimov) in (c) iz drugih zemljepisnih imen. Manjši del je formalno enak občnim, osebnim ali drugim zemljepisnim imenom in je nastal z onimizacijo ali polastnoimenjenjem $(k u k>K u k$, postaja $>$ Postaja) oz. transonimizacijo (voda Koritnica $>$ naselje Koritnica, voda 
$B a c ̌ a>$ naselje $B a c ̌ a)$, večina pa je iz teh izrazov in imen tvorjena s pomočjo značilnih imenotvornih obrazil -jane, -iči $i,-y n ' i,-j b$, -ica, -nikъ idr. (Dolje, Volče, Žabče, Ljubinj, Trebuša, Kozmerice, Drobočnik), nekatera krajevna imena pa so po tvorbi zloženke (Hudajužna), posamostaljene predložne zveze (Poljubinj, Zatolmin) in stalne besedne zveze (Most na Soči, Prapetno Brdo, Šentviška Gora idr.).

\section{Čadrg}

Bezlaj je vseskozi menil (1956: 108; 1967: 89, 92; 1976: 71), da je ime Čadrg v skladu s substitucijsko romansko-slovensko fonetiko nastalo iz romanskega občnega imena cataracta 'žleb', 'strma gorska soteska'. Toda v romanski soseščini, med Furlani, ni tovrstnih občnih imen, obenem pa je Bezlaj zanemaril dejstvo, da najstarejši zgodovinski zapisi iz let 1300-1515 ohranjajo priporniško izgovarjani g v izglasju: 1300 Zadroc, 1377 Zadroch in Çadrach, 1515 Tschadrach. Šele od leta 1523 dalje se pojavljajo zapisi brez -g: 1523 Tschadra, 1566 Zadra, enako tudi 1570, 1591, 1600, 1648, 1780, 1822, tudi v tolminski krstni knjigi 1697 Zadra, prav tam 1870 še vedno Čadra. Šele z vrnitvijo k živemu ljudskemu jeziku se v zapisih konec 19. stoletja pojavi Čadrg. Obliko Čadra so uveljavili italijanski pisarji, ki

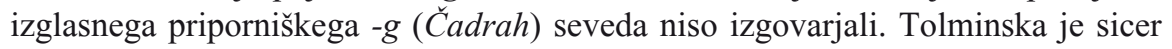
v letih 1509-1918 spadala pod Avstrijo, vendar je imela italijanščina v uradovanju precejšen vpliv.

Prebivalci Čádrga so Čádržni (knjižno Čadržani), podobno kot so prebivalci Bódreža (pri Kanalu) Bódrežni oz. Bodrežáni. Bezlaj omenja tudi ledinsko ime $\mathrm{Na}$ $\check{C}$ adrih (del gozda), $S \check{C}$ adriga (pri Avčah, terenski zapiski T. Logarja). Ko sem ime preveril na terenu, se je izkazalo, da gre za oblike $\mathrm{Na}$ Čadəry (tožilnik smeri!), bil

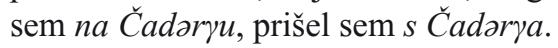

Obstaja pa še ledinsko ime Čádrug v Hostnem v Slovenski Benečiji (Hostne 1997: 73). Zapis Čadrug, ki je nedvomno samo varianta imena $\check{C} a d r g$, je odraz mlajšega narečnega razvoja.

V knjigi o imenih v občini Garmak (Bonini - Kovačov 2001: 90, 102, 108) sta navedeni ledinski imeni Čadreš in Čadrug. Čadrug je isti kot v prejšnji publikaciji in leži v neposredni bližini Čadreša. Čadreš je nedvomno samo zapis izgovora za *Čadraž, ta pa je izpeljanka s svojilnim obrazilom -jb iz imena * Čadrag.

Ledinska imena Čadrug, Čadrež v Benečiji, Čadrg v Avčah in krajevno ime Čadrg pri Tolminu kažejo na razmeroma strnjen areal imen, ki jih smemo vse izvajati iz istega antroponima *Čadragъ (Torkar 2007: 259; 2008: 25; Snoj 2009: 94).

Toponim $\check{C} a d r g$ je torej na videz nastal z navadno toponimizacijo osebnega imena * $\check{C} a d r a g b$, vendar to za srednji vek ne pride v poštev. Toponim lahko razložimo le s pridevniško rabo osebnega imena $-{ }^{*}$ Čadragz (lěss), ki je zloženka iz dveh korenskih morfemov: ča- glagola *čajati 'čakati' in *dragb 'drag'. Takšen način tvorbe zemljepisnih imen iz osebnih imen je v slovanskih jezikih razmeroma redek, vendar obstaja. Veliko pogosteje so bila zemljepisna imena izpeljana iz osebnih imen s svojilnim obrazilom -jb, ki se mu je včasih pridružilo še stanovniško obrazilo -jane, npr. dolenjske Čadraže ( $<*$ Čadragъ), Sedraž v občini Laško 
( $<*$ Sedragъ), Bodrež v občini Kanal ( $<*$ Mojdragъ, 1367 Modraz), Boldraž v občini Metlika ( $<$ *Bolédragъ). Iz istih sestavin kot Čadrg, le v drugem zaporedju, je zloženo nekdanje osebno ime *Dragočajb, iz katerega je bilo z obrazilnim morfemom -bn- izpeljano krajevno ime Dragočajna v občini Medvode.

\section{Drobočnik}

Po podatkih KLS (1968: 402) leži vas ob istoimenskem potoku, po katerem je najverjetneje prejela ime. Še leta 1880 je bil Drobočnik zaselek Tolminskega Loma in štel le 5 hiš in 25 prebivalcev (Orts-Repertorium 1885: 57), tudi Glonar (1931: 298) ga navaja še kot zaselek, medtem ko ga Imenik (1951: 167) že vodi kot samostojno naselje. Zgodovinski zapisi so razmeroma skromni: 1648 Dobaznica (Premrou 1929: 5, lokalizacija S. Torkar), 1780 Terbouzhnik (Jožefinski 1997: 43), 1798 Treboznia (Capellaris), 1822 Darabocnich (FK, k. o. Lom Tolminski), 1885 Dobročnik, danes narečno Drbóčnk.

Kljub protislovnim starim zapisom je ime mogoče rekonstruirati kot *Dobročnikъ. Današnja oblika Drobočnik je rezultat v slovenski toponimiji pogosto izpričanega premeta dobr- $>d r o b-$. Vodno in krajevno ime je izpeljano iz osebnega imena *Dobrota, ki se še danes ohranja v priimku Dobrota.

Zapis Darabocnich očitno ohranja narečno polnoglasno obliko z akanjem, prim. narečno tolminsko sarabót za srobot. Iz osebnega imena *Dobrota je s svojilnim obrazilom -jb najprej nastala oblika *Dobročb (potokъ), nato pa z obrazilom -nikъ Dobročnik oz. Drobočnik. Zapis Dobročnik iz leta 1885 je najverjetneje že (pravilni) poskus rekonstrukcije, na podlagi tega zapisa je Bezlaj (1956: 141) brez težav uvrstil vodno ime Dobročnik (videti je, da oblike Drobočnik sploh ni poznal) med izpeljanke iz prvega dela osebnih imen na Dobr-, kot so Dobroslav, Dobrogoj, Dobroteh ipd. S podobnim premetom dobr- $>$ drob- so nastala tudi slovenska krajevna imena Drobínsko ( $<$ *Dobrinsko) v občini Šentjur, Drbetinci $(<*$ Dobretinci) v Slovenskih goricah, Drabóslovica $(<*$ Dobroslavica), zaselek Podlonka v občini Železniki, Drabúnaže $(<*$ Dobroneže) in Drvéša vas $(<*$ Dobreša vas) na Koroškem, ledinsko ime Drobósljevec $(<*$ Dobrosljevec $<*$ Dobrosel $<*$ Dobroslav) v občini Komen.

$\mathrm{Z}$ enakim priponskim obrazilom kot $*$ Dobrota je tvorjeno tudi nekdanje ime * Dragota, ohranjeno v hišnem imenu Drgota v Zadlogu pri Črnem Vrhu in v krajevnem imenu Dragotinci v občini Sveti Jurij ob Ščavnici, ali pa *Črnota, ohranjeno v krajevnem imenu Črnotiče v občini Koper.

Iz antroponimske podstave Dobr- je tvorjeno tudi gorsko ime Dobrenjščica. Izpeljano je iz hipokoristika *Dobren z več obrazili: -jb, -ski in -ica.

\section{Godiča}

Pokrajinsko in vodno ime Godíča (1780 Godizha, 1822 Goditscha, FK, k. o. Poljubinj) je s poimenovalnega vidika mogoče primerjati s Trebušo, saj podobno ozna- 
- c čuje tako širše območje - pod Tolminskim Triglavom nad Poljubinjem - kot potok, [그 $\mathrm{ki}$ teče tik vasi in se izliva v Sočo.

Staroslovenska osebna imena na God-, izpričana v zgodovinskih virih, so: Godimir ( $<*$ Godimirz), Godimisl ( $<*$ Godimyslb), Godislav ( $<*$ Godislavb) in Godislava in tudi hipokoristično okrajšano ime Godeša, ohranjeno v priimku Godeša in v krajevnem imenu Godešič. Iz imen na God- je izpeljanih še več drugih slovenskih krajevnih imen: Godovič (<*Godovitb), Goče $(<*$ Godbcb), Godič in Godičevo (<*Gódit'b), Godnje (<*Goděnz), Vodiča vas, tudi Diča vas pri Beljaku (<*Godiča vas), Godimer (1316 nekje na tržaškem Krasu, Merkù 2006: 79) in Godemarci $(<*$ Godimirz), potok Godomlja $(<*$ Godomъ). Nekaj se jih je ohranilo v priimkih Godina, Godnič, Godec, Godeša, Godič.

Ime Godíča je izpeljano iz patronimika Gódič s pomočjo svojilnega obrazila -jb (Bezlaj 1956: 181) z odnosnico v ženskem spolu: Godíča (voda).

Bezlaj (1976: 155) označuje besedo god kot slovanski polisemantem (besedo z več pomeni), knjižno danes 'god, imendan', zgodovinsko in narečno tudi v pomenu 'čas' (Megiser), 'priložnost' (Trubar), goditi, goden, godnost 'zoreti, zrel, zrelost', k temu goditi, ugoditi, ugajati 'ugajati'. Omeniti velja tudi tolminski prislov payádu 'krepko, popolnoma, v redu'.

Trubačov (1979: 190) izhaja iz *goditi (se) 'ustreči, zadovoljevati'. Toporov (1993: 33) k razlagi pomena imena Godimir navaja ruski pregovor »Na ves' mir ne ugodiš' « (varianta: »Na ves' mir i sam Bog ne ugodit«) 'Vsem ni mogoče ustreči' (varianta: 'Vsem še sam Bog ne more ustreči').

\section{Hoč}

je ime 1512 m visoke vzpetine med Poreznom in Petrovim Brdom na nekdanji meji med tolminskim in loškim gospostvom. Tako kot Porezen je očitno dobil ime s cerkljanske strani še pred tirolsko kolonizacijo sredi 13. stoletja. Ime je izpeljano iz staroslovenskega osebnega imena *Hotъ (prim. današnji priimek Hotko) s starim svojilnim priponskim obrazilom -jb (vrh), podobno kot Vič $(<*$ Vitъ) in Godovič $(<*$ Godovitb) ali, z dodanim stanovniškim obrazilom -jane, Hoče pod Pohorjem.

Ime Hot je hipokoristična oblika dvočlenskih imen *Hotěmirz, *Hotědragz, *Hotébodz ipd., ki so skupaj z različnimi izpeljankami dobro zastopana v slovenski toponimiji, npr. Hobovše, Hotavlje, Hotedršica, Hotemaže, Hotemež, Hotenja, Hotič, Hotična, Hotinja vas, Hotovlja, Hotunje, ali, z glasoslovno ponemčenim vzglasjem, Kotlje, Kotmara vas, Kotredež itd.

\section{Hotenja}

Pritok Trebuše in zaselek Dolenje Trebuše (1591 Cotegna) je prejel ime po osebi z imenom *Hoten (<*Hotěnъ), ki je hipokoristik od zloženih imen na Hot-. Zanimivo je, da se tudi prebivalci Hotedršice imenujejo Hotenjci, saj je Hotedršica $(<*$ Hotedražica $<*$ Hotědragz) nekdaj imela tudi konkurenčno imensko različico 
Hotenje. Tako se je prvotno imenovala tudi vasica Hiteno v občini Bloke (1780 še Hottenie). Vodno ime Hotenja je izpeljano iz osebnega imena *Hoten s svojilnim obrazilom -jb: *Hotenja (voda).

\section{Hotešk}

Hotéšk je zaselek Idrije pri Bači na levem bregu Idrijce, kjer se potok z imenom Hoteška grapa izliva v Idrijco (TTN5). Narečna oblika imena je Hat'éščk, ${ }^{1}$ zato bi pričakovali poknjiženje v Hotešček. Ime se je prvotno gotovo nanašalo na potok in je bilo pozneje preneseno tudi na zaselek. Iz osebnega imena *Hotěšs, kar je hipokoristična oblika od zloženih imen na Hot-, je izpeljano z obraziloma -bsk- in -jakb, podobno kot Miklošičev rojstni kraj Radomerščak iz osebnega imena *Radomer. Ime *Hotěš se je ohranilo v redkih priimkih Hoteš in Hotež ter v hišnem imenu Kotež v Rodiku.

\section{Hotovlja}

je potok in domačija v Volčah (1780 Hatoule, 1813 Hateulie, FK, k. o.Volče), narečno tudi Hatujle. Ime je na TTN5 sicer zapisano v obliki Hotevlja, ki je rezultat napačnega poknjiženja. $\mathrm{V}$ tolminskem narečju prehaja diftong -ou- $\mathrm{v}-u-$ : damù $<$ domov, mùst $<$ molsti, ù $k<$ volk, $\grave{\text { Če } e ~}<$ Volče, Hùm $<$ Holm, mučát $<$ molčati, ùna $<$ volna, tùst $<$ tolst, zato tudi Hatújle $<*$ Hotovlja.

Enako se imenuje vas Hotovlja pri Poljanah nad Škofjo Loko (1485-1490 Katobly, 1780 Hotoule, 1825 Hottoule, FK, k. o. Dobje). Krajevno ime je verjetno preneseno z imena potoka, ki se danes imenuje Hotoveljska grapa.

Vodno ime Hotovlja je izpeljano iz osebnega imena *Hotъ, enako kot Radovlja $(<*$ Radı) ali Trbovlje $(<*$ Trěbъ), torej s svojilnima priponskima obraziloma $-o v$ in še $-j b$, vmes se je po vseh glasoslovnih pravilih vrinil epentetični -l-, enako kot v stari pridevniški obliki sinovlji.

\section{Kozmerice}

Že zgodovinski zapis Costameriza iz leta 1377 (Kos 1948: 49) omogoča zanesljivo rekonstrukcijo prvotne oblike imena: *Gostomeríca. To rešitev je brez vsakega komentarja nakazala že Maja Košmrlj (1970: 107), pozneje tudi avtor tega prispevka (Torkar 2008: 23).

Starejša lokalna imenska oblika se je glasila Kosmerice, ${ }^{2}$ izpričana je tudi v besedilu Cirila Kosmača Hodil po zemlji sem naši iz leta 1933 (besedilni korpus Nova beseda), v arhivskem gradivu Krajevnega narodnoosvobodilnega odbora

1 Podatek Franca Kranjca s Pečin, ustno.

2 E-pismo dr. Lenarta Barbiča z dne 17. maja 2007. 
(KNOO) Sela-Kosmerice iz leta 1945 (http://www.arhiv.gov.si) in v besedilu arheologinje Mehtilde Urleb iz leta 1975 z naslovom Kosmerice v knjigi Arheološka najdišča Slovenije, Ljubljana: SAZU (izd.) - DZS (zal.), 1975, str. 117. Zgodovinar Simon Rutar je v svojih delih uporabljal še edninsko obliko Kosmerica (Rutar 1882: 235, 249), medtem ko je Imenik krajev za Primorsko iz leta 1885 uporabljal celó obliko Gosmarica (Orts-Repertorium 1885: 59). Današnje imenske oblike so na Kozmerícah, kozmeriški, Kozmerjáni.

Zgodovinski zapisi kažejo takole sliko: 1377 Costameriça, Castomeriça, 1515 Gastameriza, 1523 Costamiritz unnder die supp Sell gehörig, 1570 Gostomarizza, ok. 1600 Gostomeriza, 1811 Cosmeriza.

Krajevno ime Kozmerice je nedvomno nastalo iz osebnega imena *Gostoměrb oz. *Gostomirb, izpričanega tako pri Slovencih kot pri drugih Slovanih: podložnik z imenom Gozmer 1253 v Bohinjski Beli (Bizjak 2006: 186), pri Poljakih Goscimier, Goscimiar, pri polabskih Slovanih Gostimer, pri Srbih in Hrvatih Gostimir, pri Bolgarih v 13. stoletju Gostimir, Gostimer. Ime je ohranjeno tudi v zemljepisnih imenih: vas Gostimirovo na obali Volge (na območju nekdanje Tverske gubernije), vas Kostimerovo v porečju Oke v okolici Rjazana, potok Gostemirec (z različicami Gostemer, Gostemir, Gostemerja, Gostemerža) je desni pritok Penke v okolici Kurska, nedaleč stran še drugi potok Gostemirec, nekdanje naselje pri Novgorodu »v Gostmeričah«, nekdanja vas Gostimerica v Bolgariji in vas Costomiru v Romuniji blizu Ploieştija (Vasiljev 2005: 242; Svoboda 1964: 76).

Starejša oblika *Gostomeríca se je razvila v dveh korakih: najprej je bila iz imena prvega naseljenca *Gostomera s starim svojilnim obrazilom -jb izpeljana *Gostomerja (vas), nato pa je bilo z obrazilom -ica to pridevniško ime posamostaljeno, podobno kot Drabóslovica $(<*$ Dobroslavъ) v občini Železniki, Hotédršica $<*$ Hotědragъ) v občini Logatec, Rádgonica (<*Radigojb) v občini Litija, Sódražica $\left(<*^{*}\right.$ Stojbdragъ). V primerjavi z naštetimi krajevnimi imeni pa je bila *Gostomeríca naglašena na obrazilu -ica, podobno kot imena Jesenica ( $<$ jêsen), Bezovica ( $<$ bez, bezeg), Poljšica ( $<*$ Poglejščica $<$ pogled), Črmošnjice (< čremoš), zato je, da bi se olajšal izgovor, iz imena izpadel drugi samoglasnik: *Gostmerica. Zatem je izpadel še $t$, podobno kot $k r s t n i k>k r s n i k$. Vzglasni $g$ - je prešel v $k$-najverjetneje pod vplivom italijanske pisave in izgovora. Množinska oblika je nastala šele v 19. stoletju po analogiji s sosednjimi imeni Modrejce, Kozaršče, Volče.

Prav na koncu, očitno šele v 20. stoletju, je prišlo še do zvenečnostne premene Kosmerice $>$ Kozmerice. Vzporednice za takšne premene najdemo v imenih Pórezen (< *Porsno < *Pódvrsno), Modrzéli (zaselek Levpe, 1780 Motore Selle < 'stara sela') idr.

Stanovniško ime Kozmerjani je tvorjeno iz prvotne pridevniške podstave *Gost(o)merja (vas), podobno kot pri Sodražici, prebivalci katere so Sodražani in ne *Sodražičani. To je dodaten dokaz za opisani tvorbeni model krajevnega imena. Poskus razlage iz domnevnega osebnega imena *Kozmarik s konverzijo iz mestniške oblike (kot $\mathrm{v}$ imenu Jesenice) je nesprejemljiv tako $\mathrm{z}$ besedotvornega vidika kot zaradi neupoštevanja zgodovinskih zapisov (Snoj 2009: 209).

Sestavino gost zasledimo še v slovenskih zemljepisnih imenih Gostinja vas (na Koroškem, <*Gostb), Gasteraj (v Slovenskih goricah, $<{ }^{*}$ Gostiradъ), Gastabil 
(gorsko ime pri Cerknem, <*Gostobylb), Dražgoše (<*Dražigostb), Gosteče (pri Škofji Loki, <*Gostęta), in v priimkih Gostiša, Gostin, Gostej, Gostič, Gosnik.

\section{Ljubinj in Poljubinj}

Imena na ljub- so bila med popularnejšimi predkrščanskimi osebnimi imeni pri starih Slovencih. Sem spadajo tudi Libušnje (<*Ljubuša), vzpetina Ljubija v Logjeh in ime naše prestolnice Ljubljana (<*Ljubovid). V virih se leta 1342 in 1344 omenjata Ljubigoj (Lubigoy) v Bohinju in še en Ljubigoj v Špetru Slovenov (Otorepec 1995: 188, 196), leta 1419 pa Ljubko (Lupcho) iz Modreja (Staffuzza 1978: 12).

Bezlaj je razlagal Ljubínj iz domnevno prvotnega vodnega imena *Ljubin potok (torej iz ženskega osebnega imena Ljuba) in menil, da je zapis Ljubinj hiperkorekten (Bezlaj 1956: 347). Vendar že H. Tuma piše, da »stari Tolminci jasno izrekajo [...] Lbinj, Polbinj (z mehkim $n$ )« (Tuma 1929: 65). ${ }^{3}$

Zgodovinski zapisi za Ljubinj so tile: 1377 Glubin, 1515 Lubein, 1523 Lubing, 1566 Lubin, 1570 Iubin, ok. 1600 in 1648 Lubin, 1756 Lublin, 1780 Lubina, 1822 Lubino, 1882 Ljubinj.

Na prvi pogled se zdi, da je Ljubinj tvorjen s svojilnim obrazilom -jb iz starega osebnega imena *L'ubinz (Snoj 2009: 238). To osebno ime je bilo pri Slovanih izpričano že leta 827 (Puchenau v Zgornji Avstriji, Kronsteiner 1975: 48), pri Srbih leta 1318 v Svetostefanski hrisovulji (Ivić - Grković 1980: 97), nekdanja osebna imena na -in pa so se ohranila tudi v slovenskih priimkih Borin, Budin, Dobrin, Radin, Svetin, Zorin ipd.

Toda primerjalno slovensko in slovansko imensko gradivo govori prej za to, da je Ljubinj izpeljan iz osebnega imena *L'ubъ s svojilnim obrazilom -yn' $i$ (Torkar 2008: 24). Poljski jezikoslovec Sławski poudarja, da »igra pripona -yn’ $i$ v slovanski onomastiki veliko vlogo« (Sławski 1974: 139). Bezlaj je šele v Esejih o slovenskem jeziku (1967: 159) priznal obstoj tega obrazila v imenih Tuhinj in Strahinj. Ti dve imeni sta dejansko nastali iz imenskih oblik *Tuhs $(<*$ Dragotuhb, prim.

3 Henrik Tuma je sicer trdil, da v imenih Ljubinj, Ljubelj, Ljubljana tiči deblo lub v samo njemu znanem pomenu 'žleb'. V svojem teoretično najambicioznejšem imenoslovnem spisu Krajevno imenoslovje, objavljenem v Jadranskem almanahu za leto 1923 v Trstu, piše (str. 127): »Krajevno imenoslovje (toponomastika) še ni znanstveno predelano. Je sicer nekaj splošnih del (Tauber, Egli), imamo številno monografij t.j. proučevanj krajevnih imen na omejenem prostoru, ki vedno bolj naraščajo in bi dale že ogromnega gradiva za sestavo sistematičnega dela.« Toda takšno sistematično delo je za slovanske jezike opravil že Miklošič v razpravah 1860-1874, ki pa jih Tuma očitno ni poznal. Kot se lahko prepričamo iz Kataloga knjižnice dr. H. Tume (Kolenc 2008), dostopnem na naslovu http://zimk.zrc-sazu.si/eknjiga/Tuma-katalog.pdf, Tuma v svoji bogati knjižnici ni imel temeljnega dela slovanskega imenoslovja, Miklošičevih treh imenoslovnih razprav iz let 1860, 1864 in 1872-1874, ki so jih ponatisnili leta 1927 v Heidelbergu. Od Miklošičevih del je imel le njegov Etimološki slovar slovanskih jezikov iz leta 1886. Če bi Tuma poznal omenjene tri Miklošičeve imenoslovne razprave, bi se njegovo ljubiteljsko imenoslovno delovanje (zlasti etimologiziranje) dvignilo na bistveno višjo raven. 
toponim Dragatuš v občini Črnomelj) in *Strahъ $(<*$ Strahomirъ). V isto skupino imen spadajo tudi Bohinj $(<* B o h ъ<* L ' u b o h ъ$, prim. krajevno ime Ljubohyni $\mathrm{v}$ Ukrajini), vodni imeni Mislinja $(<*$ Myslynja $<*$ Myslъ) in Hudinja $(<*$ Hodynja $<* H o d z)$, Hotinja vas pod Pohorjem (<*Hotynja vbsb < Hotъ). Vzporednice z Ljubinjem najdemo v hercegovskem krajevnem imenu Ljubinje, $\mathrm{v}$ češkem krajevnem imenu Libyně (Profous 1949: 605), v ruskih krajevnih imenih Ljubynja, Ljubyni, v ruskih rečnih imenih Ljubyni, Ljubyn'ka idr. (Šulgač 2003: 77).

Krajevno ime Poljubinj je nastalo iz *Podljubinj, ker leži vas pod Ljubinjem. Glas $d$ v predlogu pod je v predložnih imenih tega tipa pogosto izginjal, tako imamo že 1377 Poglubin, istega leta tudi Pomels, ki pa je od 17. stoletja dalje ponovno izpričan kot Podmeuz (danes Podmelec), ime domačije Pahóč za poknjiženi Podhoč (gl. zgoraj Hoč) in krajevno ime Pógara v Poljanski dolini, na podlagi starih zapisov poknjiženo v Podgora.

Zdi se nenavadno, da se kraj, ki je zaradi boljše lege in večjih obdelovalnih površin starejši, večji in pomembnejši od višje ležečega Ljubinja, imenuje glede na lego pod krajem, ki je nastal pozneje (po podatkih tolminskega urbarja 1377 je bilo v Poljubinju 21 kmetij, na Ljubinju pa 7). Zato je upravičena domneva, da je Ljubinj prvotno označeval širše območje, morda tudi vzpetino (prim. Ljubelj in Podljubelj, 1337 Poglubelle).

\section{Modrej in Modrejce}

Pri krajevnem imenu Modréj je Bezlaj nihal med nejasnim keltsko-romanskim substratom (Bezlaj 2003: 140) in izvajanjem iz slovanskega antroponima *Modrej na podlagi slovanskih vzporednic (Bezlaj 1961: 29). Naposled se je Snoj (2009: 266) upravičeno odločno nagnil $\mathrm{k}$ razlagi krajevnega imena iz slovanskega antroponima, izpričanega tako v slovenskem priimku Módrej kot v nekaterih zemljepisnih imenih na Slovenskem in pri drugih Slovanih: Módrič v občini Laško in še en Módrič, lok. tudi Mandrče v občini Slovenska Bistrica, Modruša kot zaselek Vinice pri Šmarjeti v občini Novo mesto, Modrínja vas pri Gosposveti na Koroškem, Modrič v Makedoniji, Modrik in Modrinje v Bosni, Modruš in Modrušani na Hrvaškem, Modřejovice, Modřišice, Modřice na Češkem (Profous 1951: 121) in Moravskem (Hosák - Šrámek 1980: 89), Modryči v karpatski Ukrajini (Hudaš 2004: 231).

Slovenski priimki Moder, Modrič in Modrej imajo v svoji podstavi pridevnik moder $(<*$ modr $r)$ v pomenu 'modre barve' in ne moder $(<*$ mQdr $b)$ v pomenu 'pameten' (iz te podstave je priimek Modrijan), isto pa velja tudi za našteta zemljepisna imena, ki so vsa nastala iz ustreznih starih osebnih imen.

Pri razlagi krajevnega imena Modréj (domačini sicer naglašajo Módrej, nar. Màdri) se postavlja vprašanje, ali je bilo to iz osebnega imena *Modrějı prvotno izpeljano s katerim od priponskih obrazil ali pa imamo opraviti z navadno toponimizacijo osebnega imena, torej z redkim tipom transonimizacije: oseba Modrej > naselje Modrej. Slednje v bistvu zagovarja Snoj (2009: 266), saj domneva, da je krajevno ime Modrej nastalo prek predložne zveze *pri Modreju v pomenu 'naselbina človeka z imenom Modrej'. Toda ta tip tvorbe je v toponimiji sorazmerno mlad 
pojav in ga nikakor ne moremo predpostavljati za srednji vek. Če ime ni izpeljanka, je Modrej najverjetneje nastal na enak način kot $\check{C} a d r g$ z elipso iz pridevniške rabe - *Modrejb (lěş).

Toda zdi se, da je krajevno ime Modrej vendarle nastalo z izpeljavo, ki nam je ostala prikrita zaradi poznejše konverzije imena iz rodilnika množine $\mathrm{v}$ novi imenovalnik ednine. Zgodovinske zapise, ki začenši z letom 1377 in skoraj brez izjeme vse do prvih slovenskih zapisov v drugi polovici 19. stoletja izkazujejo obliko Modrea (le leta 1607 je izpričan zapis Modrei grande), je namreč mogoče brati kot *Modréje, torej v množinski obliki (prim. zapise Gabria za Gabrje, Volaria za Volarje, Doglia za Dolje, Descla za Deskle). V literaturi je dejansko mogoče zaslediti množinsko rabo. Publicist Rado Bednarik $(1932: 15,192)$ piše: »Južno od Ljubinja nad Modrejami ..., ... pod cesto v Modreje ..., Modreje, kakor tudi Modrejce na nasprotnem bregu, so lepe, nove vasice. Nekoč so bile Modreje sedež celega okraja.« Pisatelj Ivan Pregelj v Tolmincih uporablja Modrej v ednini, le enkrat v množini: »Po poti niz Modreje je našel ježa« (besedilni korpus Nova beseda).

Množinsko ime Modréje je mogoče razložiti kot izpeljanko s svojilnim obrazilom -jb in stanovniškim obrazilom -jane v pomenu 'prebivalci Modrejevega naselja', prvotno *Modréjane, pozneje skrčeno v Modreje. Na takšen način je iz *Volk nastalo ime Volče. Novejša edninska oblika Modrej je nastala s konverzijo iz rodilnika množine: prihajam, sem iz Modrej. S takšno konverzijo so na Tolminskem in Cerkljanskem nastala imena Podmelec, Zakraj, Selc, Otalež, drugod po Sloveniji pa še Godešič, Kotredež, Hotemež, Žalec, Mokronog, Rakičan idr. (Torkar 2009: 414).

Obstaja pa še manjša možnost, da je italijanski zapis Modrea odražal nekdanjo slovensko obliko *Modreje v ednini ali celo *Modreja, kar bi pomenilo, da je to pridevniška tvorjenka iz osebnega imena *Modrej z obrazilom -jb, torej *Modreje (selo, polje, brdo) oz. *Modreja (vas). Današnja moška oblika Modrej bi pomenila konkurenčno različico iste pridevniške tvorjenke $\mathrm{z}-\mathrm{jb}$, ki se ni nanašala na odnosnico selo ali vas, ampak na neki samostalnik moškega spola, npr. vrh, potok, les.

Krajevno ime Modrejce je Bezlaj (1967: 88) razlagal kot stanovniško ime tipa Gorenjci. Prebivalci Modreja so sicer Modréjani (KLS 1968: 413); SKI navaja napačen naglas Modrejàn (1985: 175). Toda naselji Modrej in Modrejce, ki ležita eno nasproti drugemu, prvo na levem, drugo na desnem bregu Soče, sta dejansko v razmerju veliki : mali, o čemer pričajo tudi nekateri zgodovinski zapisi s konca 16. in v začetku 17. stoletja. V nemških virih se takrat pojavlja za Modrejce zapis Klein Modrei, v italijanskih pa leta 1607 (redundantno) Modreica picola (za Modrej pa Modrei grande). Po podatkih tolminskega urbarja iz leta 1377 je bilo v Modreju 15 kmetij, na Modrejcah pa 10 (Kos 1948: 57-58). Na poimenovanji pa ni vplivala le velikost, temveč gotovo tudi lega vasi in od nje odvisen čas njenega nastanka. Krajevni imeni *Modreje in *Modrejice sta v enakem razmerju kot Hinje in Hinjce v občini Sevnica (oboje v okolici Šentjanža), ki sta v turjaški listini iz leta 1467 zapisani kot Grossen Vichna in Klain Vichna. Kot se je za *Male Hinje razvilo ime *Hinjice (standardizirana je narečna oblika Hinjce) in kot se je iz krajevnega imena Telče v občini Sevnica (1825 Teltsche) sicer šele v 19. stoletju za ime zaselka te vasi razvila manjšalnica Telčice (1825 še Teltsche), tako je tudi *Modrejice (danes pač Modrejce) le manjšalnica za *Modreje. V enakem razmerju sta tudi Senadole 
v občini Divača in Senadolice v občini Sežana (1780 Veliko Snadolie in Malo Snadolie), pa tudi Repen in Repnič v občini Repentabor (1494 Gross Rieppen in Klain Rieppen).

\section{Roče}

Med krajevna imena, ki jih doslej še nihče od jezikoslovcev ni skušal etimologizirati, spadajo Roče na Šentviški planoti. Najstarejši zapisi so 1377 Roçach, 1515 in 1523 Ratschach, 1566 Rosach, 1591 Rozach, 1598 Rotschach, 1600 Rozane, 1648 Rozach, 1780 Rozha, 1822 Roche (FK, k. o. Slap ob Idrijci). Zapis Rozane jasno kaže na stanovniško obrazilo -jane, dva zapisa Ratschach iz začetka 16. stoletja pa kažeta na sovpadanje z zgodovinskimi zapisi za krajevni imeni Ráteče in Rádeče (obe mn.); Ráteče: 1385 Ratschach, 1467-1471 Ratatscha(ch), 1689 Radatsche, 1780 in 1826 Ratschach; Rádeče: 1297 Razach, 1336 in 1428 Ratschach, 1336 Ratsach, 1464 Rotschach, 1496 Roczach, 1575 Radazhai (Trubar: V Loci per Radazhaju), 1581 Rozza, 1689 Ratschach, Radezche, Radezej (Valvasor), ok. 1780 Ratschach $=$ Radezhe = Brodomizh (Pohlin pri Kastelcu in Vorencu, Stabej 1997: 550), 1825 Ratschach. Pintar (1905: 688), Ramovš (1924: 251), Skok (1934: 61) in Bezlaj (1961: 134) so Radeče utemeljeno razlagali iz Radęt-je (selo) s stanovniškim obrazilom -jane. Snoj (2009: 341) se je pri razlagi tega imena vrnil k Škrabcu (1896), ki je Radeče izvajal iz patronimične oblike *Radiči, ne da bi preveril zgodovinske zapise (zadoščal bi že Valvasor).

Glede na primerjalne zgodovinske zapise lahko v imenu Roče s precejšnjo gotovostjo prepoznamo antroponimsko podstavo Rad-, glede na današnje imenske oblike pa ga lahko izvajamo iz osebnega imena *Radec (<* $\operatorname{Rad} \mathbf{c} \mathbf{b})$, kar je hipokoristik k zloženim imenom Radoslav, Radegoj, Radočaj ipd. V imenu tičita svojilno obrazilo -jb in stanovniško -jane, kar je dalo *Radčane, nato z asimilacijo *Račane. Kot je razvidno iz zgoraj navedenega zgodovinskega gradiva, je $a$ v teh imenih občasno prehajal v $o$. Zakaj je ravno na Tolminskem že zgodaj prišlo do glasovne premene naglašenega $a$ v o (*Radčane $>*$ Rodčane $>$ Roče), bo treba še pojasniti.

Omeniti pa velja še dve krajevni imeni iz antroponimske podstave Rad- v osrednji in vzhodni Sloveniji, kjer je podobno prevladala oblika z o: Rodež pri Zagorju ob Savi (<*Radeš) z zgodovinskima zapisoma 1448 Rodes (v latinskem viru) in 1526 Radesch (v nemškem viru); Rodni vrh pri Ptuju (<*Radni), med letoma 1440 in 1461 osem zapisov: Radwen, Radoway, Radowen, Radwen, Radendorf, Radwentz, Radwantz, Radewoy.

Zapisovanje etimološkega $a \mathrm{z} o$ zasledimo v virih razmeroma pogosto: $R a-$ dénci v Beli krajini so leta 1576 izpričani v obliki Rodentz, medtem ko so v latinsko pisanem viru leta 1581 Prebačevo pri Kranju ovekovečili kot Priboz, Vače pa kot Boz. Radánja vas pri Stični se v viru iz leta 1780 pojavlja kot Rodena vasz.

Imenska podstava Rad- je izpričana tudi v gorskem imenu Radómažna nad cerkljanskimi Ravnami, izpeljanem iz osebnega imena *Radomož (<*Radomožъ) in izpričanem še v krajevnih imenih Rodmošci pri Gornji Radgoni in Radmožanci pri Lendavi. 


\section{Samotešnik}

je ledinsko ime v Idriji pri Bači in ime tamkajšnjega zaselka, ki je na TTN5 vpisano kot Samotežnik. Toda živa ljudska izreka je Samatíšnk ${ }^{4}$ in to je dober dokaz, da ledinsko ime nima zveze z ljudskoetimološko razlago, ki jo je zapisal že pisatelj Ciril Kosmač leta 1953 v delu Pot v Tolmin: »,Lepo ime, kaj, Samotežnik?‘ je navdušeno rekel oče. ,Najbrž prihaja od tod, ker je hiša vrh klanca in je bilo treba k njej vse pripeljati samotež.' " (Besedilni korpus Nova beseda)

Prav to ledinsko ime je izpričano že v tolminskem urbarju 1377 pri naselbini Trušna (zaselek Idrije pri Bači) kot ime travnika Somotesina, ki je bil v lasti nekega Bratigoja (Kos 1948: 72). Dejstvo, da je bilo ime takrat izpeljano z obrazilom -ina, kaže na konkurenčnost obrazil -ina in -nik, poznano tudi v številnih drugih primerih v slovenski toponimiji (Slavina - Slavnik, Slatina - Slatnik, Rakitina - Rakitnik idr.). Zemljepisno ime Samotešnik smo upravičeni izvajati iz znanega slovanskega osebnega imena *Semiteh $(<*$ Sěmitěhъ). Zemljepisno ime se je prvotno glasilo *Sěmitěšina, pozneje *Sěmotěšina, nato zaradi asimilacije že zgodaj preosmišljeno v Samotešina, naposled pa je prevladala izvedba z enakopomenskim obrazilom -nik. Zelo podoben glasovni razvoj je doživelo krajevno ime Samotišky na Moravskem, zapisano leta 1131 Semitesicih, 1239 in villa Semitessich, 1517 pa že v Samotižkách (Hosák - Šrámek 1980: 421).

Staroslovensko osebno ime Semiteh je v zgodovinskih virih izpričano v 12. stoletju na Štajerskem kot Zemtech in Scemitech, zloženo pa je iz korenskih morfemov *sěmb v pomenu 'oseba' (temu sorodno je rus. sembja 'družina') in -těh(prim. uteha, tešiti). Semiteh je torej 'tisti, ki koga miri, tolaži'. V virih so za čas od 9. do 14. stoletja izpričana številna druga staroslovenska imena na *Sem-: Zemibond (< * Sěmibodъ), Zemidrud (<*Sěmidrugъ), Zemigneu (<*Sěmigněvъ), Cemicas (< *Sěmikazъ), Zeminech $(<*$ Sěminěgъ), Zemizlaua $(<*$ Sémislava), Semislau (<*Sémislavb) (Kronsteiner 1975: 62-63). Nekatera so se ohranila v krajevnih imenih, npr. Semislavče pri Rožeku na Koroškem (1201 Semislau), Svinča vas na Koroškem (1130-1205 Zemegoisdorf<* Sěmigojb), Semič v Beli krajini, medtem ko čisto vzporednico imenu Samotešnik najdemo danes v krajevnih imenih Semeteš pri Raški v Srbiji in Semetiš pri Kaknju v Bosni ter v vodnem imenu Semeteško jezero v jugozahodni Srbiji (Imenik 1951). Temu sorodna so še druga v Srbiji izpričana krajevna imena, kot so Semegnjevo (<*Sěmigněvъ), Semedraž in Samodraža ( $<*$ Sěmidragъ), od katerih prav pri slednjem vidimo enako preosmislitev prvega dela ( *Semi- $>$ Samo-) kot pri našem Samotešniku.

Korenski morfem -těh-zasledimo tudi v imenu Dobrteša vas (<*Dobrotěhb), ki pa je obstajalo le do leta 1999, saj je naselje odtlej del Šempetra v Savinjski dolini. Iz osebnega imena *Dragotěhı je bilo izpeljano krajevno ime *Dragoteš (1291, 1501 Dragotes, Dragotess), kot se je v srednjeveških urbarjih imenovala vas Dolenje Brdo v Poljanski dolini.

4 Podatek Franca Kranjca s Pečin, ustno. 


\section{Trebuša}

Krajevno in pokrajinsko ime Trebuša je zaradi bogate asociativnosti nenehno predmet vseh mogočih ljubiteljskih razlag, čeprav je bilo v jezikoslovni literaturi nedvoumno razloženo - posredno - že pri Miklošiču (1860: 321; 1864: 65) in - neposredno - pri Bezlaju (1961: 271), nazadnje tudi pri Snoju (2009: 438).

Ime Trebuša je s svojilnim obrazilom -jb izpeljano iz osebnega imena *Trěbuhъ, ki je hipokoristična oz. okrajšana oblika enega od zloženih osebnih imen na Treb-: *Trěbégostb, *Trěběgojb (prim. krajevno ime Terbégovci), *Trébovids (prim. krajevno ime Trebija) itd. Najlepše se to vidi iz zgodovinskih zapisov za krajevno ime Trebuška vas, ki označuje zaselek Šmartna pri Slovenj Gradcu: 1411 Trebegotsch, Trebegotschach (*Trebegošče <*Trěběgostb), ok. 1480 Tribusch, ok. 1780 Trebuscha.

Enako kot Trebuša so tvorjena še krajevna imena Gorjuša v občini Domžale $(<*$ Gor'uhb $<*$ Gorislavb), Dobruša v občini Vodice $(<*$ Dobruhъ $<*$ Dobrogojb, *Dobroslavb), s pritaknjenim stanovniškim obrazilom -jane pa Gorjuše in Raduše $(<*$ Raduhb $<*$ Radoslavb, *Radigojb). Pač pa je Trebuhinja, ime zaselka vasi Brezen pri Vitanju, z zgodovinskimi zapisi 1403/04 Trebechin, Trebichin itd., izpeljana iz osebnega imena *Trěbuhı z obrazilom -yn'i, tako kot Ljubinj, Mislinja, Hotinja vas itd.

Snoj je bil sprva mnenja (Snoj pri Bezlaju 2005: 217), da je v zemljepisnih imenih težko razlikovati med osnovo iz glagola trebiti 'krčiti gozd' in tvorbami iz antroponimov Trěběgojb ipd. Pozneje (Snoj 2009: 434-438) se je pri večini etimologiziranih imen na Treb-začel odločneje nagibati v prid izantroponimskega izvora teh imen. Na podlagi pretresa slovenskih krajevnih imen na Treb- in primerjave z drugim slovanskim gradivom lahko dejansko z veliko gotovostjo trdimo, da velika večina izvira iz staroslovenskih antroponimov, npr. Trbovlje, Trebče, Trabénče, Trebénče, Trebeljévo, Trebija, Trebinja, Trébljenje, Trabésinje, Trebéše, Trébnje, Terbégovci, Trpčáne, Tarbílj idr. Podstava osebnih imen na Treb- je trěba v pomenu 'žrtev, obred, daritev bogovom', kar je izpeljano iz glagola *terbiti 'trebiti, čistiti, krčiti', zato je žrtvovanje mogoče razumeti kot »očiščevalno dejanje« (Toporov 1993: 57; Snoj pri Bezlaju 2005: 217). Mnenje, ki ga navaja Simon Rutar (1882: 22), da »pomeni Trebuša toliko kot kraj darovanja, očiščevanja«, je torej napačno, saj je iz besede trěba izpeljano že osebno, ne pa šele zemljepisno ime.

Zemljepisno ime Trebuša je nastalo kot pokrajinsko in ne kot naselbinsko ime. In der Trabusch leta 1491 še ni pomenilo naselja, ampak obširno gozdnato območje v dolini z reko, ki se danes imenuje Trebušica. Naselje v spodnjem, tolminskem delu se je pojavilo šele v začetku 16. stoletja (Trpin 2001: 48), v zgornjem, goriškem delu pa še pozneje. Ime Trebuša potemtakem lahko rekonstruiramo kot *Trebuša (= *Trebuhova) dolina. Nastalo je očitno nekoč v srednjem veku in skupaj z imeni Čepovan, Kanomlja, Blegoš, Lubnik, ki so tipološko enakega nastanka, dokazuje, da so naši predniki onomastično osvojili celotno naše ozemlje, še preden so ga fizično gosteje poselili. 


\section{Volče}

se ponašajo z najstarejšim zgodovinskim zapisom na Tolminskem. Leta 1015 so prišle v zgodovino kot Walzana, kar je latinski zapis starejše slovenske oblike *Volčane. Podobno skrčenje obrazila so doživela številna krajevna imena s stanovniškim obrazilom -jane. Roče so še ok. 1600 zapisane kot Rozane, za Šebrelje na Cerkljanskem se v narečju še ohranja neskrčena oblika Šebrejlene. Pogosteje so imena neskrčeno obliko ohranila le v rodilniku. Dolje so v viru iz leta 1523 zapisane z rodilniško obliko Dolian, Vipolže v Brdih ohranjajo prvotno rodilniško obliko v italijanski varianti Vipulsano. Za Dutovlje na Krasu se čedalje redkeje sliši stara rodilniška oblika iz Dutovljan.

Stanovniška imena na -jane so nastajala tako iz zemljepisnih občnih in lastnih imen (npr. Goričane < gorica ali Gorica, Kozjane < Kozji vrh) kot iz osebnih imen, le da so bila iz prvih tvorjena največkrat (ne pa vselej) neposredno, iz drugih pa izključno prek njihovih svojilnopridevniških izpeljank (Mertelj - Bezlaj 1960/61: 221). Dražgoše namreč niso izpeljane z obrazilom -jane neposredno iz osebnega imena *Dražigost, pač pa iz njegove pridevniške oblike *Dražigošč $(<*$ Dražigostjb). Za Volče sicer ni mogoče zanesljivo trditi, ali so nastale iz osebnega imena Volk $(<*$ Vإkъ) ali iz občnega imena volk, v vsakem primeru pa so izpeljane iz pridevniške podstave *Volč- $\left(<* V_{b} l k-j b\right)$ oz. *volč-. Na katero odnosnico se je pridevnik nanašal, ne vemo, lahko pa sklepamo, da na katerega od zemljepisnih pojmov (potok, polje, dol, brdo), skoraj gotovo pa ne na naselbinski pojem (vas, selo). Krajevna imena na -jane so prvotno označevale le skupino ljudi, nastajala pa so po formuli: nenaselbinsko zemljepisno ali občno ime (npr. gora) > stanovniško ime (Gorjane - 'prebivalci gore ali pod goro') > krajevno ime (Gorjane, danes Gorje). Zgodovinski zapisi za nekatera imena na -jane, npr. Sebenje (zaselek Zasipa pri Bledu), nekdaj *Sebenje selo (1075 Zebeinzalo, 1319 in pozneje le še Sebeniach), Mavhinje (pri Trstu), nekdaj *Malbhynja sela (1113 Malchinasella), sicer na prvi pogled nasprotujejo tej formuli, vendar v teh primerih priponsko obrazilo -jane ni prvotno, temveč se je začelo uporabljati po analogiji.

\section{Žabče}

Po mnenju poznavalcev staroslovanskega imenskega fonda so že v praslovanščini ločili med imeni in vzdevki. Številna, gotovo pa ne vsa živalska in rastlinska imena (bober, volk, medved, zajec, orel, kragulj; hren, hrast) smemo uvrščati med stara rojstna imena, katerih namen je bil, da se skupaj z imenom na človeka prenesejo lastnosti, kot so bojevitost, pogum, zdravje. Nekatera živalska in rastlinska imena, ki so jih nosili naši predniki, pa so nastala tudi kot vzdevki.

V primerjavi s pogosto pojavljajočimi se krajevnimi imeni Žabja vas, Žabnica, Žabjek, Žablje, ki so nedvomno posredno ali neposredno izpeljana iz občnega imena žaba, je krajevno ime Žabče nastalo kot patronimično ime *Žabiči v pomenu 'potomci oz. pripadniki rodu človeka z vzdevkom *Žaba'. Obstoj patronimičnega 
- $\quad$ obrazila -ič potrjujejo tudi zgodovinski zapisi: 1377 Sabicha, 1515 Sabiza, 1523

저 Sabitscha, 1600 Sabich, 1780 Schabsche, 1822 Sabig.

$\mathrm{Na}$ enak način so nastale koroške Žabiče, vipavske Vrabče, Črnotiče, Doslovče, Juršče ( $<*$ Juršiče $<*$ Juričiče), Lahovče, Libeliče, Petrovče, Paloviče, Žaloviče idr.

\section{Viri}

Bednarik $1932=\mathrm{R}$. Bednarik, Goriška in Tržaška pokrajina v besedi in podobi, Gorica, 1932.

Bizjak 2006 = M. Bizjak, Urbarji Briksenske škofije, Ljubljana, 2006.

Capellaris $1798=$ G. A. Capellaris, Carta topografica di tutto il territorio del Friuli Goriziano ed Udinese, Venezia, 1798 (zemljevid).

$\mathrm{FK}=$ Franciscejski kataster (http://www.arhiv.gov.si/).

Glonar 1931 = J. Glonar, Poučni slovar 1, Ljubljana,1931.

Imenik 1951 = Imenik naseljenih mesta u FNRJ: stanje 1 januara 1951 godine, Beograd.

Jožefinski 1995-2001 = Slovenija na vojaškem zemljevidu 1763-1787 1-7, ur. V. Rajšp, Ljubljana, 1995-2001.

Stabej 1997 = J. Stabej, Slovensko-latinski slovar, po: Matija Kastelec - Gregor Vorenc, Dictionarium latino-carniolicum (1680-1710), Ljubljana, 1997.

KLS $1968=$ Krajevni leksikon Slovenije I, ur. R. Savnik, Ljubljana.

Kos 1948 = M. Kos, Urbarji slovenskega Primorja I, Ljubljana, 1948.

Orts-Repertorium 1885 = Special-Orts-Repertorium vom Küstenlande $=$ Repertorio speciale dei luoghi nel Litorale $=$ Poseben krajevni imenik za Primorje $=$ Posebni popis miestah u Primorju, Wien, 1885.

Otorepec 1995 = B. Otorepec, Gradivo za slovensko zgodovino v arhivih in bibliotekah Vidma (Udine) 1270-1405, Ljubljana, 1995.

Rutar 1882 = S. Rutar, Zgodovina Tolminskega, Gorica, 1882.

SKI 1985 = F. Jakopin idr., Slovenska krajevna imena, Ljubljana.

Staffuzza 1978 = B. Staffuzza, Vertenza tra Modrea e Volzana ai primi del 1419, Gorizia, 1978.

TTN 5 = Geodetska uprava Republike Slovenije, Temeljni topografski načrti, $1: 5.000$.

\section{Literatura}

Bezlaj 1956 = F. Bezlaj, Slovenska vodna imena I, Ljubljana, 1956.

Bezlaj $1961=$ F. Bezlaj, Slovenska vodna imena II, Ljubljana, 1961.

Bezlaj $1967=$ F. Bezlaj, Eseji o slovenskem jeziku, Ljubljana, 1967.

Bezlaj 1976=F. Bezlaj, Etimološki slovar slovenskega jezika 1: A-J, Ljubljana, 1976.

Bezlaj 2003 = F. Bezlaj, Zbrani jezikoslovni spisi I-II, ur. M. Furlan, Ljubljana, 2003. 
Bezlaj 2005 = F. Bezlaj, Etimološki slovar slovenskega jezika 4: ̌̌-Ž, Ljubljana, 2005. Avtorji gesel F. Bezlaj, M. Snoj in M. Furlan, ur. M. Snoj in M. Furlan.

Bonini - Kovačov 2001 = F. Bonini - Kovačov, Imena v Garmiškem kamune, Špeter, 2001.

Cieślikowa $2000=$ A. Cieślikowa, Słownik etymologiczno-motywacyjny staropolskich nazw osobowych 1, Kraków, 2000.

Hosák - Šrámek 1980 = L. Hosák - R. Šrámek, Místní jména na Moravě a ve Slezsku II: $M-\check{Z}$, Praha, 1980.

Hostne 1997 = Hostne - Costne med zgodovino in legendo, Lesa, 1997.

Hudaš 2004 = M. Худаш, Украӥнські карпатські $i$ прикарпатські назви населених пунктів (утворення від відапелятивних антропонімів), Львів, 2004.

Ivić - Grković $1980=$ П. Ивић - М. Грковић, Топоними антропонимијског порекла у Светостефанској хрисовуљи (1318), Втора југословенска ономастичка конференција, Скопје, 1980, 95-108.

Košmrlj 1970 = M. Košmrlj, Dvočlenska antroponima v slovenskih krajevnih imenih, Onomastica Jugoslavica 2, Ljubljana, 1970, 102-117.

Kronsteiner 1975 = O. Kronsteiner, Die alpenslawischen Personennamen, Wien, 1975.

Merkù 2006 = P. Merkù, Krajevno imenoslovje na slovenskem zahodu, ur. M. Furlan - S. Torkar, Ljubljana, 2006.

Mertelj - Bezlaj 1960/61 = D. Mertelj - F. Bezlaj, Slovenska krajevna imena na -jane, Po seminarski nalogi D. Mertlja priredil za tisk F. Bezlaj, Jezik in slovstvo 6 (1960/61), 187-192, 220-225. Ponatis v: Bezlaj 2003: 197-206.

Miklošič 1860 = F. Miklošič, Die Bildung der slavischen Personennamen, Wien, 1860.

Miklošič 1864 = F. Miklošič, Die Bildung der Ortsnamen aus Personennamen im Slavischen, Wien, 1864.

Miklošič 1872-1874 = F. Miklošič, Die slavischen Ortsnamen aus Appellativen I-II, Wien, 1872-1874.

Pintar 1905 = L. Pintar, Kdaj je bil Trubar v Loki?, Ljubljanski zvon 25 (1905), 203-209, 687-690.

Premrou 1929 = M. Premrou, Una descrizione della Contea di Gorizia del 1648, Studi Goriziani (Gorizia) 7 (1929).

Profous 1949 = A. Profous, Místní jména v Čechách, jejich vznik, původní význam a změny II, Praha, 1949.

Profous $1951=$ A. Profous, Místní jména v Čechách, jejich vznik, pưvodní význam a změny III, Praha, 1951.

Ramovš 1924 = F. Ramovš, 1924: Historična gramatika slovenskega jezika II: konzonantizem, Ljubljana, 1924.

Skok 1934 = P. Skok, Iz slovenačke toponomastike II, Etnolog 7 (1934), 51-87.

Sławski 1974 = F. Sławski, Zarys słowotwórstwa prasłowiańskiego, v: Słownik prastowiański 1, Wrocław idr., 1974, 43-141.

Snoj 2009 = M. Snoj, Etimološki slovar slovenskih zemljepisnih imen, Ljubljana, 2009. 
Svoboda 1964 = J. Svoboda, Staročeská osobni jména a naše př́immení, Praha, 1964. Škrabec 1896 = S. Škrabec, 1896: Radeče?, Cvetje z vertov sv. Frančiška (Gorica) 15 (1896), št. 1; Še enkrat »Radiče«, Cvetje z vertov sv. Frančiška (Gorica) 15 (1896), št. 3. Ponatis v: S. Škrabec, Jezikoslovna dela 2, ur. J. Toporišič, Nova Gorica, 1994, 250, 258.

Šulgač 2003 = В. П. Шульгач, К реконструкции праславянского лексического фонда: производные на *-уnь (на основе ономастического материала »Новгородских писцовых книг«, Студії з ономастики та етимології (Київ) 2003.

Toporov 1993 = В. Н. Топоров, Праславянская культура в зеркале собственных имен (элемент *mir-), v: История, культура, этнография и фольклор славянских народов: ХІ Международный съезд славистов, Москва, 1993.

Torkar 2007 = S. Torkar, O neprepoznanih ali napačno prepoznanih slovanskih antroponimih v slovenskih zemljepisnih imenih: Čadrg, Litija, Trebija, Ljubija, Ljubljana, Biljana, v: Folia onomastica Croatica (Zagreb) 16 (2007), 257-273.

Torkar $2008=$ S. Torkar, Slovenska zemljepisna imena, nastala iz slovanskih antroponimov, Slavistična revija 56 (2008), kongresna številka, 17-29.

Torkar $2009=\mathrm{S}$. Torkar, Flektivna derivacija $\mathrm{v}$ slovenskih krajevnih imenih (jezikovnozgodovinski vidik), Slavistična revija 56-57 (2008, št. 4 - 2009, št. 1), Trubarjeva številka, 411-419.

Trpin 2001 = D. Trpin, Tolminska na začetku habsburške oblasti in njen urbar iz leta 1524: magistrsko delo, Nova Gorica, 2001 (rkp.).

Trubačov 1979 = О. Н. Трубачев (ur.), Этимологический словарь славянских языков: праславянский лексический фонд 6 (*e-*golva), Москва, 1979.

Tuma 1929 = H. Tuma, Imenoslovje Julijskih Alp, Ljubljana, 1929.

Vasiljev 2005 = В. Л. Васильев, Архаическая топонимия Новгородской земли, Великий Новгород, 2005.

\section{Slavic anthroponyms in the toponymy of the Tolmin region}

\section{Summary}

This article examines seventeen geographical names from the Tolmin area that arose on the basis of Slavic personal names: Čadrg, Drobočnik, Godiča, Hoč, Hotenja, Hotešk, Hotovlja, Kozmerice, Ljubinj and Poljubinj, Modrej and Modrejce, Roče, Samotešnik, Trebuša, Volče, and Žabče. Today fourteen of these refer to settlements and hamlets, among which some were originally hydronyms: Drobočnik, Hotenja, and Hotešk. Today only Hotovlja remains a hydronym. The names Godiča and Trebuša were originally choronyms and hydronyms; the name Trebuša later also became a place name. There is only one oronym: Hoč.

The majority of the names were created using the old possessive suffix $-j b$ : Godiča, Hoč, Hotenja, Hotovlja, Ljubinj, Poljubinj, and Trebuša, sometimes joined 
by the suffix -nikb (Drobočnik and Samotešnik), the suffix -ica as a result of sub- stantivization (Kozmerice) or as a diminutive (Modrejce), or the gentilic suffix -jane (Modrej, Roče, and Volče). The name Hotešk is formed with the suffixes -bsk- and -jakb, and the name Žab̌ce with the patronymic suffix -ič $(<-i t$ ' $b)$, whereas $\check{C} a d r g$ was apparently created with the suffix $-b$, which is merely a result of the adjectival use of the personal name *Cadragz.

The names Modrej, Roče, Volče, and Žabče are gentilics in origin that originally designated groups of people and only later also the places where they settled. 